УДК 349.2

DOI https://doi.org/10.32849/2663-5313/2020.11.11

\title{
Тамара Кириченко,
}

здобувач

Східноукраїнського національного університету імені Володимира Даля

\section{ОПТИМІЗАЦІЯ ПРАВОВОГО РЕГУЛЮВАННЯ ТРУДОВИХ ВІДНОСИН В УКРАЇНІ}

Україна обрала для себе шлях суверенної незалежної демократичної держави, що поставило перед нею ряд задач стратегічного характеру. У процесі їх вирішення було здійснено перехід від плановоі економіки до ринкової, держава відмовилась командно-адміністративних методів здійснення державної політики, було створено власну правову систему, яка відповідає специфічі геополітичного становища України. Одна зі сфер, яка потребувала стратегічного впливу держави, а саме трудові правовідносини, так і не набула адекватного правового забезпечення. Незважаючи на те, що правове регулювання трудових правовідносин зазнавало змін та розвивалось протягом усього часу після здобуття Україною незалежності, запроваджені заходи виявились недостатніми для забезпечення ефективного правового регулювання трудових правовідносин, $i$ законодавство, яке здійснює регламентацію таких правовідносин, все ще потребує своєі оптимізації і дотепер. У даній статті нами здійснено дослідження питання оптимізащії правового регулювання трудових правовідносин в Украіні. Встановлено, які напрями оптимізації є першочерговими натепер, та розкрито сутність кожного з них. Зроблено висновок, що прийняття Трудового кодексу України є першочерговим напрямом оптимізації правового регулювання трудових правовідносин в Україні, враховуючи те, що новий Трудовий кодекс України є стратегічною задачею Верховної Ради нового скликання. Вітчизняний законодавець здійснює безуспішні спроби розробити та прийняти такий нормативно-правовий акт уже понад десятиліття, і його прийняття дійсно є важливим у світлі проблематики чинного Кодексу законів про прачюо України. Адаптація трудового законодавства до стандартів Європейського Союзу здійснюється тривалий період. Для ивого в Україні функиіонує спечіальне нормативне та інституиійне забезпечення. Як наслідок, будь-який нормативно-правовий акт, що приймається в Україні для регулювання трудових правовідносин, має бути адаптований до положень асqиіs Європейського Союзу. Останній виділений нами напрям оптимізації правового регулювання трудових правовідносин в Україні полягає у використанні досвіду європейських держав. Реалізаиія даного напряму є важливою у світлі європейського вибору Украӥни для подальшого прачевлаштування громадян України в Свропейському Союзі, та громадян Свропейського Союзу в Украйні.

Ключові слова: трудові правовідносини, трудове законодавство, оптимізація законодавства, удосконалення законодавства, Трудовий кодекс, адаптація законодавства.

Постановка проблеми. Сучасний стан правового регулювання трудових правовідносин в Україні можна охарактеризувати як такий, що потребує оптимізації. Трудові правовідносини все ще врегульовуються Кодексом законів про працю України [1], прийнятим ще за радянської епохи, а процеси вдосконалення трудового законодавства мають здебільшого хаотичний і некомплексний характер, що, з одного боку, відображається на неузгодженості правових норм, а із іншого - не вирішує всі наявні проблеми правового регулювання трудових правовідносин та не дозволяе заповнити наявні прогалини. Вітчизняними дослідниками регулярно наголошується на необхідності приведення норм трудового права у відповідність до сучасних реалій, адже в багатьох аспектах Кодекс законів про працю України [1] та інші акти трудового законодавства не відповідають сучасним реаліям. 3 одного боку, вони не врегульовують належним чином окремі аспекти трудових правовідносин, які останнім часом набули актуальності (зокрема, щодо новітніх форм зайнятості), а з іншого - містять термінологію, встановлюють інститути та базуються на правових традиціях, які є застарілими в сучасних реаліях (наприклад, щодо виплати заробітної плати не рідше двох разів на місяць через проміжок часу, що не перевищує шістнадцяти календарних днів).

Наведене вище свідчить про те, що питання оптимізації правового регулювання трудових правовідносин в Україні залишається вкрай актуальним, навіть незважаючи на кількість праць, які були йому присвячені. Повільне оновлення трудового законодавства, помилки, які були вчинені законодавцем у проведенні такого оновлення, а також 
необхідність в оновленні законодавства, яке врегульовує трудові правовідносини в Україні, можна пов'язати зі слабким науковим розробленням концептуальних засад оптимізації правового регулювання трудових правовідносин. Також варто враховувати те, що сфера трудових правовідносин $є$ такою, яка не стоїть на місці, постійно змінюється та оновлюється. Даний факт також має стимулювати вітчизняного законодавця вдосконалювати їх правове регулювання, а вітчизняних науковців - здійснювати пошук найбільш оптимальних шляхів для цього.

У вітчизняній науковій літературі питанню оптимізації правового регулювання трудових правовідносин в Україні присвячено велику кількість наукових праць. Серед тих дослідників, які в тій чи іншій мірі звертались до здійснення пошуків шляхів для вдосконалення трудового законодавства України, відзначимо внесок таких, як: Ю.А. Андрушко, Д.С. Бойчук, Н.Б. Болотіна, В.С. Венедіктов, О.С. Гапон, С.В. Грищак, М.О. Дей, М.С. Демидович, А.Ю. Денисевич, М.I. Іншин, Т.М. Кириченко, Т.В. Колєснік, В.В. Лазор, Л.І. Лазор, Р.З. Лівшиц, Ю.О. Марчук, К.В. Мельник, Т.І. Мостицька, Н.М. Мужикова, Д.С. Овсянко, О.Л. Омельченко, Ю.П. Орловський, П.Д. Пилипенко, С.М. Прилипко, О.В Прилипчук, О.С. Проневич, О.І. Процевський, В.Ф. Пузирний, К.Б. Пусан, В.Г. Ротань, Л.А. Семиног, О.А. Теличко, Г.С. Хаварівська, Н.М. Хуторян, Г.І. Чанишева, Ю.П. Шемчушенко, O.M. Ярошенко та велика кількість інших дослідників. Проте той факт, що законодавство, яке врегульовує трудові правовідносини, все ще залишається недосконалим, свідчить про актуальність здійснення досліджень напрямів його оптимізації.

Мета статті полягає у встановленні того, якими $є$ найбільш ефективні напрями оптимізації правового регулювання трудових правовідносин в Україні, в чому полягає їхня сутність, та яким чином вони можуть бути втілені на практиці вітчизня॥ ним законодавцем.

Виклад основного матеріалу. Враховуючи інтерес дослідників до питання проблем трудового законодавства та пошуку шляхів їхнього вирішення, в науковій літературі склалось декілька стійких напрямів, які розглядаються вітчизняними науковцями, як кроки законодавця, що дозволять оптимізувати правове регулювання трудових правовідносин.

Так, аналіз наукової літератури дозволяє зробити висновок, що сьогодні найбільш актуальними є такі напрями оптимізації пра- вового регулювання трудових правовідносин в Україні:

1) прийняття Трудового кодексу України та скасування актів, які не відповідають вимогам сучасності (наприклад, даний напрям досліджується у праці Г.С. Хаварівської [2]);

2) адаптація трудового законодавства до стандартів Європейського Союзу (даний напрям розкривали у своїх працях О.С. Проневич [3], М.С. Демидович [4], Д.С. Овсянко [5], Ю.А. Андрушко [6], А.Ю. Денисевич [7], О.В. Прилипчук [8], Т.М. Кириченко [9], Ю.О. Марчук та Д.С. Бойчук [10];

3) використання досвіду держав, які оптимізували правове регулювання трудових правовідносин (на актуальності даного напряму наголошують Є.Б. Кубко [11], Д.С. Овсянко [12], В.К. Забігайло [13] та велика кількість дослідників, які досліджували правове регулювання трудових правовідносин в окремих державах світу).

Перший виділений нами напрям, а саме прийняття Трудового кодексу України та скасування актів, які не відповідають вимогам сучасності, $є$ таким, на актуальності якого наголошують фактично всі дослідники проблем правового регулювання трудових правовідносин. Так, натепер основою трудового законодавства України є Кодекс законів про працю України [1], прийнятий ще 10 грудня 1971 р. До змісту даного нормативно-правового акту за останніх 29 років було внесено чимало змін і доповнень, зокрема, було прийнято понад 60 законів про внесення змін. Як наслідок, із 265-ти статей та преамбули, які містились у першій редакції Кодексу законів про працю України [1], суттєво змінились 235 (деякі 3 них - неодноразово). Тому натепер даний нормативно-правовий акт, як відзначає Г.С. Хаварівська, являє собою «суміш правових норм, прийняту за різних історичних та економічних умов, певна частина яких відповідає вимогам часу, а інша - застаріла i не може адекватно регулювати сучасні трудові відносини [2, с. 156]. Тому потреба в прийнятті нового Трудового кодексу України, з одного боку, зумовлена змінами системи суспільних відносин, які відбуваються в Україні, а з іншого - чинний Кодекс законів про працю України [1] зазнавав змін настільки багато разів, що внаслідок цього відбулось виникнення великої кількості проблем різної визначеності, які роблять недоцільним подальше внесення змін до цього нормативно-правового акту.

Перша спроба прийняти новий Трудовий кодекс в Україні була датована 2007 роком, коли Верховною Радою було зареєстровано проект № 1108 від 14.02.2007 року [14]. 
Даний законопроект навіть пройшов перше читання, втім, у результаті його так і не було прийнято. Проект був доволі прохолодно прийнятий суспільством та вітчизняними науковцями, адже його зміст включав норми, які дозволяли в окремих випадках змушувати працівника перепрацьовувати понад установлену граничну норму робочого часу. Стаття 380 проекту передбачала можливість для роботодавця протидіяти страйкам працівників шляхом «локауту», тобто тимчасової зупинки роботи підприємства чи істотного скорочення обсягів виробництва 3 одночасним припиненням виплати заробітної плати. Розкритикованим було право роботодавця звільняти працівників за розголошення державної, комерційної або іншої захищеної законом інформації, адже сам факт розголошення працівником такої інформації доволі складно перевірити та довести на практиці. Проект містив у тому числі й ряд позитивних положень, наприклад у частині правового регулювання укладення трудового договору чи в частині відпусток, проте його прийняття в такому вигляді могло би призвести до катастрофічних наслідків, тож аж до 2012 року його, незважаючи на численні правки, так і не було включено до порядку денного для голосування.

Наступна спроба прийняти Трудовий кодекс мала місце в 2013 році, коли було зареєстровано проект № 2902 від 22.04.2013 року [14]. Даний законопроект оцінювався на науковому рівні як доопрацьована версія проекту № 1108, в якому були усунені його численні недоліки. Його автори оптимізували питання робочого часу, повернувши граничну норму робочого часу 40 годин, а будьяке «перепрацювання» мало бути передбачено трудовим договором або погоджено 3 профспілкою та оплачено в подвійному розмірі. Було встановлено заборону локауту та ряд інших доволі позитивних новел, які стосувались правового регулювання трудового договору, відпусток, оплати праці. Звернемо увагу також на те, що попри критику, в проекті № 2902 від 22.04.2013 року [14] не було виправлено ряд спірних моментів, наприклад, щодо звільнення працівників за розголошення державної, комерційної або іншої захищеної законом інформації. Залишилася без змін норма, у відповідності до якої роботодавець із метою контролю за виконанням трудових обов'язків працівниками міг здійснювати спостереження за ними за допомогою технічних засобів. Також доволі неоднозначно була сприйнята нова норма, згідно 3 якою в роботодавця з'являлось право звільнити працівника, який відмовився робити щеплення. Незважаючи на те, що даний проект був суттєво досконалішим, аніж проект № 1108 від 14.02.2007 р. [14], його у 2014 році було відкликано у зв'язку з підготовкою нового проекту.

Після Революції Гідності оптимізація правового регулювання трудових правовідносин знову актуалізувалась. Серед низки реформ, передбачених Коаліційною угодою Верховної Ради України VIII скликання, була і реформа трудових правовідносин, основною складовою частиною якої стало зобов'язання депутатів протягом 2015 р. схвалити новий Трудовий кодекс (п. 4 розділу IX Коаліційної угоди від 27.11.2014р.), для чого було підготовлено новий проект від 27.12.2014 р. № 1658 [16, с. 156]. Даний проект у 2015 році було прийнято в першому читанні, відправлено на доопрацювання, яке закінчили у 2017 році й у кінцевому результаті так і не прийняли. Серед позитивних новел проекту Закону України від 27.12.2014 р. № 1658 [16] відзначимо те, що ним передбачалась єдина письмова форма трудового договору, що мало би позитивно вплинути на захист прав працівників. Набула своєї регламентації робота на умовах ненормованого робочого часу, гнучкий режим роботи та дистанційна праця. Планувалось, що зміст трудової функції за кожною професією і відповідною кваліфікацією мав визначатись законодавством, а в частині, не визначеній законодавством, - кваліфікаційними характеристиками. При цьому будь-яка робота, яка виходила за межі кваліфікаційних характеристик, мала оплачуватись додатково. Було відзначено позитивно збільшення на чотири дні мінімальної тривалості щорічної основної відпустки, яка тепер не могла становити менше 28 днів. Перелік підстав для звільнення було оптимізовано шляхом відмови від такої підстави, як звільнення за переведенням на інше підприємство. Даний перелік було доповнено такими підставами, як: відсутність працівника та інформації про причини такої відсутності більше чотирьох місяців, смерть працівника, настання надзвичайних обставин, що перешкоджають продовженню трудових відносин (наприклад, військові дії). Досить спірним було повернення обов'язку реєстрації укладених фізичними особами-підприємцями трудових договорів 3 найманими працівниками в Центрах зайнятості та розширення прав державних інспекторів праці. Загалом, даний проект було сприйнято значно позитивніше, аніж попередні, втім, він також не був прийнятий.

Новий проект Трудового кодексу № 2410 було розроблено чинною Верховною Радою України IX скликання [17], і він одразу був розкритикований як експертами, 
так і науковцями з огляду на значне розширення прав роботодавців. Серед позитивних аспектів проекту № 2410 від 08.11.2019 р варто відзначити нормативне закріплення дистанційної форми зайнятості та урегулювання питання трудових відносин тимчасових працівників. Даний момент є дуже важливим, адже дистанційна праця є затребуваною на ринку праці, але на даний момент так і не була урегульована законодавцем. Набув регламентації порядок припинення трудових відносин у випадку смерті роботодавця-фізичної особи, визнання його безвісно відсутнім або оголошення померлим. Було збільшено тривалість щорічної відпустки з 24 до 28 днів та визначено інститут професійної кар'єри й засоби її здійснення. Більш досконало було захищено права вагітних жінок, які згідно з проектом на час проведення медичних обстежень можуть бути звільнені від виконання роботи, і при цьому за ними зберігається середня зарплата. Згідно 3 проектом № 2410 [17] випробувальний термін повинен становити не більше трьох місяців, а для робочих спеціальностей - всього один місяць. Втім, відзначимо, що даний законопроект, незважаючи на плани щодо його прийняття у 2020 році, так і залишається в підвішеному стані, і його майбутнє на даний момент є незрозумілим. Разом із проектом № 2410 [17] було зареєстровано альтернативний законопроект № 2410-1 [18], перспективи прийняття якого $€$ також незрозумілими.

Отже, прийняття Трудового кодексу України та скасування актів, які не відповідають вимогам сучасності (передусім Кодексу законів про працю України [1]), $€$, на нашу думку, ключовим напрямом для оптимізації правового регулювання трудових правовідносин в Україні. Нами встановлено, що вітчизняний законодавець неодноразово здійснював спроби оптимізувати трудове законодавство в такий спосіб, проте поки безрезультативно. Втім, кількість проектів Трудового кодексу України свідчить про розуміння законодавцем різних скликань важливості прийняття даного нормативно-правового акту, тому очевидно, що в майбутньому даний напрям оптимізації буде реалізовано.

Наступним напрямом оптимізації правового регулювання трудових правовідносин в Україні, на нашу думку, є адаптація трудового законодавства до стандартів Європейського Союзу. У вітчизняній науковій літературі наявна велика кількість праць, в яких зміст Кодексу законів про працю України [1] аналізується через призму його невідповідності європейським стандартам у сфері регулювання трудових правовідносин. Наприклад, Ю.О. Марчук та Д.С. Бойчук дійшли висновку, що норми Кодексу законів про працю України [1] у контексті його відповідності принципам рівності та заборони дискримінації не відповідають вимогам статті 19 Європейської соціальної Хартії та статті 6 й 7 Міжнародного пакту про економічні, соціальні та культурні права, адже вони не закріплюють стандарти працевлаштування іноземців, які відповідають європейським» $[10$, с. 8]. Тобто з огляду на це $є$ очевидним, що оптимізація правового регулювання трудових правовідносин в Україні не може бути досягнутою до тих пір, поки вітчизняне трудове законодавство не буде адаптоване до стандартів Європейського Союзу в цій сфері.

На науковому рівні розглядаються різні концепції того, яким чином має відбуватись оптимізація згідно з даним напрямом наявні концепції щодо потреби в уніфікації термінології та вироблення сталої системи юридичних понять і термінів у досліджуваній нами сфері [4, с. 58; 19, с. 108-109]; підкреслюється важливість активізації науковців, зокрема шляхом збільшення кількості наукових конференцій чи круглих столів задля публічного обговорення проблем адаптації [3, с. 37-38]; відзначається необхідність зближення вітчизняного трудового законодавства із трудовим законодавством європейських держав [7, с. 106]; наголошується на необхідності прийняття нових нормативно-правових актів, які врегульовують трудові правовідносини, та зміст яких узгоджується з європейськими стандартами [8, с. 8; 20, с. 330]. I в даному контексті відзначимо те, що робота 3 адаптації трудового законодавства до стандартів Європейського Союзу ведеться вітчизняним законодавцем уже не перший рік.

Так, згідно з частиною 1 статті 51 Угоди про партнерство і співробітництво між Україною i Європейськими співтовариствами та їх державами-членами від 14 червня 1994 року [21], Україна визнала необхідність необхідності зближення існуючого і майбутнього законодавства України із законодавством Свропейського Союзу та взяла на себе зобов'язання вжити заходи для забезпечення приведення у відповідність національного законодавства до законодавства Співтовариства. Для виконання цього зобов'язання Україною було прийнято Стратегію інтеграції до Європейського Союзу [22], згідноз якою адаптація законодавства України до законодавства $\mathrm{CC}$ визначалась як один з основних напрямів інтеграційного процесу. Як наслідок, Україною було ратифіковано Конвенцію 
про захист прав людини і основоположних свобод [23], Європейську соціальну хартію (переглянуту) [24], ряд конвенцій Міжнародної організації праці (Конвенцію № 2 про безробіття 1919 року [26], № 811947 року про інспекцію праці в промисловості й торгівлі [27] та № 1291969 року про інспекцію праці в сільському господарстві [28], що позитивним чином відобразилось на оптимізації правового регулювання трудових правовідносин. Згодом було прийнято Закон України «Про Загальнодержавну програму адаптації законодавства України до законодавства Європейського Союзу» від 18.03.2004 р. № 1629-IV [25], яким було визначено, що $є$ європейським законодавством та які джерела його становлять. Також в Україні функціонує Департамент міжнародного права Міністерства юстиції України.

Все вищенаведене свідчить про те, що адаптація трудового законодавства до стандартів Європейського Союзу розглядається законодавцем та вітчизняними науковцями як один із найважливіших напрямів оптимізації правового регулювання трудових правовідносин в Україні. Робота над адаптацією ведеться вже не перший рік, в рамках якої законодавець здійснює ратифікацію європейських та міжнародних стандартів, приводить акти національного законодавства у відповідність до актів європейського законодавства, перевіряє законопроекти, які мають прийматись у майбутньому, на відповідність європейським та міжнародним стандартам. Важливість адаптації трудового законодавства до стандартів Європейського Союзу полягає в тому, що в майбутньому Україна бачить себе членом Європейського Співтовариства. Втім, в умовах, коли правове регулювання трудових правовідносин здійснюється в Україні нормативно-правовими актами, прийнятими ще в радянську епоху, вирішення такої задачі $є$ сильно ускладненим.

Останнім виділеним нами напрямом оптимізації правового регулювання трудових правовідносин в Україні є використання досвіду держав, які оптимізували правове регулювання трудових правовідносин. Варто підкреслити, що європейський вибір України полягає не лише в членстві в європейських організаціях, а й у всебічному входженні до європейської спільноти. А отже, погодимось із Д.С. Овсянко в тому, що, ставлячи перед собою мету наближення національної правової системи до правової системи Свропейського Союзу, оптимізація правового регулювання трудових правовідносин в Україні має бути спрямована таким чином, щоб в іiї основі перебувало найбільш прогресивне та досконале світове законодавство, яке формувалося протягом тривалого часу і відображає досвід багатьох країн [12, с. 287-288]. І в даному контексті дійдемо висновку, що у вітчизняного законодавця наявне розуміння щодо цієї проблематики.

Насамперед відзначимо, що весь час після проголошення Україною незалежності вітчизняний законодавець у законотворчій діяльності спирався на досвід іноземних держав. На перших порах зразком для запозичення слугувало законодавство пострадянських республік, проте після проголошення євроінтеграції ключовим напрямом зовнішньополітичного курсу України в Постанові Верховної Ради України «Про основні напрями зовнішньої політики України» від 02.07.1993 р. № 3360-XII [29] законодавчий досвід держав-членів Європейського Союзу став першочерговим для запозичення Україною. Погодимося з академіком Ю.С. Шемшученком у тому, що використання досвіду держав, які оптимізували правове регулювання трудових правовідносин, не може здійснюватись механічно через принцип державного суверенітету кожної країни, національні особливості різних держав, відсутність універсальних організаційних механізмів гармонізації відповідних правових систем та недоліки в теоретичному вирішенні відповідних проблем, що стримує і їх практичне вирішення [11, с. 35]. Тому в даному контексті звернемо увагу на те, що процес використання досвіду держав, які оптимізували правове регулювання трудових правовідносин, включає низку етапів, під час яких перевіряється можливість реалізації такого досвіду в Україні. У відповідності до Закону України «Про Загальнодержавну програму адаптації законодавства України до законодавства Європейського Союзу» від 18.03.2004 р. № 1629-IV [25] проекти законів України та інших нормативно-правових актів перевіряються на їх відповідність acquis communautaire $з$ метою недопущення прийняття актів, які суперечать acquis Європейського Союзу. Тобто нові нормативно-правові акти трудового законодавства приймаються в Україні на основі досвіду європейських держав, напрацьованого ними роками. Окрім того, Україна регулярно отримує експертну та консультативну допомогу від європейських держав у питаннях законодавства. Також вітчизняними фахівцями аналізується позитивний досвід європейських держав у регламентації трудових правовідносин. А тому наявні підстави для висновку, що процес імплементації трудового законодавства Європейського Союзу в систему трудового законодавства 
України здійснюється через призму національних правових та соціально-економічних особливостей нашої держави.

Як відзначає В.К. Забігайло, закономірності взаємодії права та економіки (політики) у здійсненні адаптації законодавства України в цілому поки що фактично ігноруються, а реалії життя українського суспільства «ще далеко не завжди і не в усіх сферах рівнозначно $€$ адекватними умовам, характерним для європейського співробітництва» [13, с. 24]. На сфері правового регулювання трудових правовідносин дане правило відображається найбільш відчутно. На нашу думку, саме через такі розходження проекти Трудового кодексу № 1108 від 14.02.2007 р. [14], № 2902 від 22.04.2013 р. [15], № 1658 від 27.12.2014 р. [16], № 2410 від 08.11.2019 р. [17] та № 2 410-1 від 08.11.2019р. [18] і були розкритиковані вітчизняними науковцями, адже вони були розроблені на основі досвіду зарубіжних держав без урахування національних правових та соціально-економічних особливостей нашої держави. А отже, зробимо висновок, що використання досвіду держав, які оптимізували правове регулювання трудових правовідносин, є важливим напрямом оптимізації правового регулювання трудових правовідносин в Україні, проте таке запозичення потребує активізації наукової спільноти нашої держави.

Таким чином, використання досвіду держав, які оптимізували правове регулювання трудових правовідносин, є одним із напрямів оптимізації правового регулювання трудових правовідносин в Україні, який полягає в аналізі трудового законодавства іноземних держав (передусім держав-членів Свропейського Союзу) та в інтеграції його позитивних аспектів у систему трудового права України.

\section{Висновки}

Отже, дослідивши питання оптимізації правового регулювання трудових правовідносин в Україні, ми зробили висновок, що найактуальнішими та найефективнішими його напрямами $є$ прийняття Трудового кодексу України, адаптація трудового законодавства до стандартів Європейського Союзу та використання досвіду держав, які оптимізували правове регулювання трудових правовідносин.

Прийняття Трудового кодексу України, на нашу думку, є першочерговим напрямом оптимізації правового регулювання трудових правовідносин в Україні, враховуючи те, що новий Трудовий кодекс України є стратегічною задачею Верховної Ради нового скликання. Вітчизняний законодавець здійснює безуспішні спроби розробити та прийняти такий нормативно-правовий акт уже понад десятиліття, і його прийняття дійсно є важливим у світлі проблематики чинного Кодексу законів про працю України. Адаптація трудового законодавства до стандартів Свропейського Союзу здійснюється тривалий період. Для цього в Україні функціонує спеціальне нормативне та інституційне забезпечення. Як наслідок, будь-який нормативно-правовий акт, що приймається в Україні для регулювання трудових правовідносин, має бути адаптований до положень асquis Свропейського Союзу. Останній виділений нами напрям оптимізації правового регулювання трудових правовідносин в Україні полягає у використанні досвіду європейських держав. Реалізація даного напряму є важливою у світлі європейського вибору України для подальшого працевлаштування громадян України в Свропейському Союзі та громадян Європейського Союзу в Україні.

\section{Список використаних джерел:}

1. Удосконалення національного трудового законодавства за допомогою механізму імплементації міжнародних трудових стандартів. Право $i$ суспільство. 2013. № 6.2. С. 150-154.

2. Марчук Ю.О., Бойчук Д.С. Адаптація трудового законодавства України до міжнародних стандартів європейського союзу. International Scientific Journal «Internauka». URL: https://cutt.ly/ Cd5128d (дата звернення: 17.08.2020).

3. Кубко Е.Б. Совершенствование законодательства Украины и проблемы его гармонизации с законодательством зарубежных стран. Проблемы гармонизаиии законодательства Украины и стран Европы / под общ. ред. Е.Б. Кубко, В.В. Цветкова. Киев : ЮринкомИнтер, 2003. С. 61-78.

4. Овсянко Д.С. Оптимізація та удосконалення адаптації національного законодавства про відповідальність до законодавства Європейського Союзу. Вісник Чернівещького факультету Національного університету «Одеська юридична академія», 2016. Вип. 2. С. 286-298.

5. Забігайло В.К. Право як інструмент реформування українського суспільства: законодавчі сподівання та соціальна реальність. Україн. часопис міжнар. права. 2002. № 4. С. 20-25.

6. Трудовий кодекс України : проект Закону України від 14.02.2007 р. № 1108. URL: http:// w1.c1.rada.gov.ua/pls/zweb2/webproc4_1?pf3511= 30947 (дата звернення: 04.11.2020).

7. Трудовий кодекс України : проект Закону України від 22.04.2013 р. № 2902. URL: https:// w1.c1.rada.gov.ua/pls/zweb2/webproc4_1?pf3511= 46746 (дата звернення: 04.11.2020).

8. Трудовий кодекс України : проект Закону України від 27.12.2014 р. № 1658. URL: https:// w1.c1.rada.gov.ua/pls/zweb2/webproc4_1?pf3511= 53221 (дата звернення: 04.11.2020). 
9. Трудовий кодекс України : проект Закону України від 08.11.2019 р. № 2410. URL: https:// w1.c1.rada.gov.ua/pls/zweb2/webproc4_1?pf3511= 67331 (дата звернення: 04.11.2020).

10. Трудовий кодекс України : проект Закону України від 08.11.2019 р. № 2410. URL: https:// w1.c1.rada.gov.ua/pls/zweb2/webproc4_1?pf3511= 67334 (дата звернення: 04.11.2020).

11. Шемшученко Ю. Теоретичні проблеми гармонізації законодавства України з європейським правом. Вісник Академії правових наук. 2004. Вип. 3 (38). С. 108-109.

12. Кантор Н. Теоретичні і практичні проблеми адаптації права України до права СС у сфері прав людини в умовах євроінтеграції. Актуальні питання гуманітарних наук. 2015. Вип. 11. С. 326-332.

13. Угода про партнерство і співробітництво між Україною i Європейськими Співтовариствами та іх державами-членами. Міжнародний документ від 14.06.1994 р. Офіиійний вісник України. 29.06.2006. № 24. С. 203. Ст. 1794. Код акта $36581 / 2006$. України до Європейського Союзу : Указ Президента України від 11.06.1998 р. № 615/98. Офіиійний вісник Украӥни. 1998. № 24. С. 3. Ст. 870. Код акта 5501/1998.

15. Конвенція про захист прав людини і основоположних свобод : Міжнародний документ від
14. Про затвердження Стратегії інтеграції

04.11.1950 р. Офіиійний вісник Украӥни. 1998. № 13, № 32 від 23.08.2006. С. 270 .

16. Європейська соціальна хартія (переглянута): Міжнародний документ від 03.05.1996. Відомості Верховної Ради України. 2007. № 51. C. 2096.

17. Про Загальнодержавну програму адаптації законодавства України до законодавства Європейського Союзу : Закон України від 18.03.2004 p. № 1629-IV. Відомості Верховної Ради України. 16.07.2004. № 29. С. 367.

18. Конвенція МОП N 2 про безробіття 1919 року: Міжнародний документ від 29.10.1919 р. № 2. Офіиійний вісник Украӥни. 2007. № 63. С. 124. Ст. 2489. Код акта 40796/2007.

19. Конвенція Міжнародної організації праці № 811947 року про інспекцію праці у промисловості й торгівлі: Міжнародний документ від 11.07.1947 р. № 81. Відомості Верховної Ради Украӥни. 2005. № 24. С. 1058.

20. Конвенція Міжнародної організації праці № 1291969 року про інспекцію праці в сільському господарстві: Міжнародний документ від 25.06.1969 p. № 129. URL: https://zakon.rada.gov.ua/ laws/show/993 114 (дата звернення: 04.11.2020).

21. Про Основні напрями зовнішньої політики України : Постанова Верховної Ради України від 02.07.1993 р. № 3360-ХІІ. Відомості Верховноі Ради Украйни. 1993. № 37. Ст. 379.

Tamara Kyrychenko. Optimization of legal regulation of labor relations in Ukraine

Ukraine has chosen the path of a sovereign independent democratic state, which has set a number of strategic challenges. In the process of solving them, Ukraine made the transition from a planned to a market economy. The state abandoned the command-and-control methods of implementing state policy and created its own legal system that corresponds to the specifics of Ukraine's geopolitical situation. Labor relations is one of the areas that required strategic influence of the state, and it has not acquired adequate legal support. Despite the fact that the legal regulation of labor relations has changed and developed since Ukraine's independence, the implemented measures were insufficient to ensure effective legal regulation of labor relations, so the legislation that regulates such legal relations still needs to be optimized. In this article we have studied the issue of optimizing the legal regulation of labor relations in Ukraine. We established which areas of optimization are priority today, and on this basis we have explored the essence of each of them. It is concluded that the adoption of the Labor Code of Ukraine is a priority for optimizing the legal regulation of labor relations in Ukraine, given that the new Labor Code of Ukraine is a strategic task of the Verkhovna Rada of the new convocation. The domestic legislator has been making unsuccessful attempts to develop and adopt such a normative legal act for more than a decade, and its adoption is really important in light of the issues of the current Labor Code of Ukraine. The adaptation of labor legislation to the standards of the European Union has been going on for a long time. For this purpose, special regulatory and institutional support operates in Ukraine. As a result, any legal act adopted in Ukraine to regulate labor relations must be adapted to the provisions of the acquis of the European Union. The last direction we have identified for optimizing the legal regulation of labor relations in Ukraine is to use the experience of European countries. The implementation of this direction is important in the light of Ukraine's European choice for further employment of Ukrainian citizens in the European Union and European Union citizens in Ukraine.

Key words: labor relations, labor legislation, optimization of legislation, improvement of legislation, Labor Code, adaptation of legislation. 